\title{
Biosynthesis of Silver Nanoparticles Using Rosa canina Extract and Its Anti-cancer and Anti- metastatic Activity on Human Colon Adenocarcinoma Cell Line HT29
}

\author{
Rosa canina Özü̈tü Kullanılarak Gümüş Nanopartiküllerin Biyosentę̧i ve İnsan Kolon Adenokarsinoma Hücre Hattı \\ HT29 Üzerindeki Anti-kanser ve Anti-metastatik. Aktivitesi
}

\section{Çiğdem AYDIN ACAR* ${ }^{*}$ (D), Suray PEHLIVANOĞLU2 ${ }^{2}$}

\author{
${ }^{1}$ Burdur Mehmet Akif Ersoy University, Bucak School of Health, Burdur, Turkey \\ ${ }^{2}$ Necmettin Erbakan University, Department of Molecular Biology and Genetics, Konya, Turkey
}

\begin{abstract}
Despite progress in conventional treatment methods for colon cancer, it remains the fourth leading cause of cancer-related deaths in the world. Therefore, more effective new treatment strategies for colon cancer are needed. Silver nanoparticles (AgNPs) synthesized using plant extracts have shown therapeutic applications and make it to be a good anti-cancer candidates. The aim of this study was to evaluate the anti-metastatic and anti-cancer activity of biosynthesized silver nanoparticles from Rosa canina extract on the human colon adenocarcinoma cell line HT29. The biosynthesis of AgNPs was carried out using Rosa canina extract. R-AgNPs were characterized by techniques such as UV-vis spectrophotometer and scaining electron microscopy (SEM). HT29 cells were incubated with different concentrations of AgNPs $(0-20 \mu \mathrm{g} / \mathrm{mL})$ for $48 \mathrm{~h}$. The cytotoxic activity of the synthesized R-AgNPs against human colon adenocarcinoma cells HT29 was investigated by MTT assay and the IC50 value were found to be $7,89 \mu \mathrm{g} / \mathrm{mL}$ at $48 \mathrm{~h}$ incubation. Anti-metastatic potential of R-AgNPs were determined on HT29 cells using scratch assay. RAgNPs induced a significant decrease of cell motility in dose-dependent manner. In conlusion, these findings suggest that the biosynthesized AgNPs may be promising new therapeutic agents for the treatment of human colon cancer. Keywords: Silver nanoparticles, Colon cancer, Metastasis, AgNPs.
\end{abstract}

Öz: Kolon kanseri, geleneksel tedavi yöntemlerinde kaydedilen ilerlemelere rağmen, dünyada kansere bağlı ölüm nedenleri arasında dördüncü sırada yer almaktadır. Bu nedenle, kolon kanserinin tedavisi için daha etkili yeni tedavi stratejilerine ihtiyaç duyulmaktadır. Bitki özleri kullanılarak sentezlenen gümüş nanopartiküller (AgNP’ler), terapötik uygulamalar göstermiş ve bu durum onları iyi bir kanser önleyici ajan adayı haline getirmiştir. Bu çalışmada, kuşburnu özütü ile sentezlenmiş gümüş nanopartiküllerin insan kolon adenokarsinoma hücre hatt1 HT29 üzerindeki antimetastatik ve anti-kanser aktivitesinin değerlendirilmesi amaçlanmıştır. Gümüş nanopartiküllerin biyolojik sentezi, kuşburnu bitkisinin sulu özütü kullanılarak gerçekleştirildi. R-AgNP'ler, UV-görünür spektrofotometre ve taramalı elektron mikroskobu (SEM) gibi çeşitli analitik tekniklerle karakterize edildi. HT29 hücreleri 48 saat süresince çeşitli konsantrasyonlarda R-AgNP'lerle $(0-20 \mu \mathrm{g} / \mathrm{mL})$ muamele edildi. Sentezlenen R-AgNP'lerin insan kolon kanseri hücrelerine karşı sitotoksik aktivitesi MTT assay ile değerlendirildi ve IC50 değerinin 48 saatlik inkübasyon sonucunda $7,89 \mu \mathrm{g} / \mathrm{mL}$ olduğu belirlendi. R-AgNP'lerin anti-metastatik potansiyeli, HT29 hücreleri üzerinde scratch assay kullanılarak çalışıldı. R-AgNP'lerin doza bağımlı olarak hücre hareketliliğinde önemli bir azalmaya neden olduğu belirlendi. Sonuç olarak, bu bulgular biyosentezlenen gümüş nanopartiküllerin insan kolon kanseri tedavisi için umut verici yeni terapötik ajanlar olabileceğini göstermektedir.

\begin{tabular}{ll}
\hline Anahtar Kelimeler: Gümüş nanopartiküller, Kolon kanseri, Metastaz, AgNP. \\
\hline${ }^{*}$ Corresponding author : Çiğdem AYDIN ACAR & e-mail : cacar@mehmetakif.edu.tr \\
Geliş tarihi / Received : 29.11 .2019 & Kabul tarihi / Accepted: 12.12.2019 \\
\hline
\end{tabular}

\section{Introduction}

Colorectal cancer, also known as colon cancer, is a type of cancer that begins in the colon. Colon cancer is the third leading cause of cancer-related deaths worldwide. In 2018, it was diagnosed in 
over one million people and caused death to 880,792 persons worldwide (Bray et al., 2018). Colon cancer risk factors include a person's lifestyle, diet, age, ethnicity and family history (Slattery, 2000). Although some types of cancer are preventable, this is not the case for colon cancer because colon cancer is often detected in advanced stages and is usually not diagnosed until symptoms appear. There are a variety of traditional treatment options such as surgery, radiotherapy and chemotherapy for treating this cancer, but the success rates is very low in advanced stage colon cancer. Because of all these reasons new treatment models in the treatment of colon cancer patients are needed.

Nanotechnology is a rapidly growing area with the advances in science and technology that, aims to produce new materials on the nanoscale (Albrecht et al., 2006). In past decades, metal nanoparticles have been used frequently as new anti-cancer agents owing to their features like cytotoxicity, functionality and compatibility. Especially, silver nanoparticles (AgNPs) have attracted the attention of researchers due to their various industrial applications (Yesilot and Aydin, 2019). AgNPs can be synthesized using physical, chemical and biological methods. The chemical synthesis is a commonly used approach for the synthesis of AgNPs that use toxic chemicals, leading to noneco-friendly biological products. In the recent years, green synthesis is preferred due to it is cost effective, environment friendly and easily synthesize large quantities properties compared to other methods (Thakkar et al., 2010). For the green synthesis of nanoparticles, plants extracts, bacteria, fungi, algae, yeast and viruses, which are naturally available resources can be used (Ahmed et al., 2016; Raveendran et al., 2003; Daphne et al., 2018). Plant-mediated synthesis is seen as the most suitable method among green synthesis methods because it allows the formation of more stable nanoparticles in a short time (Iravani, 2011).

Rosehip (Rosa canina) is a species of plant belonging to the Rosa genus in the Rosaceae family. Rose hip are widely distributed in several areas, including Europe, Africa, Middle and West Asia and Anatolia. In recent years, rosehip has been consumed in many cultures as a food and has been used frequently for the treatment of some diseases and has attracted more attention due to its documented therapeutical properties (Chrubasik et al., 2007). Rose hip contains high concentrations of ascorbic acid, phenolic compounds and healthy fatty acids (Larsen et al., 2003). It is a medicinal plant commonly used in traditional medicine for the treatment of colds, asthma, hemorrhoids, infections, chronic pains, arthritis, and inflammatory diseases. Also, rose hip is known to have many biological properties such as diuretic, anti-oxidant, anti-ulcerogenic, anti-obesity, antidiabetic, anti-carcinogenic, neuroprotective, and anti-microbial effects (Mármol et al., 2017; Cheng et al., 2016; Turan et al., 2017). Thus, in this study, we investigated the synthesis of AgNPs using an aqueous extract of the rose hip and evaluated their anti-cancer and anti-metastatic activities on human colon cancer cells.

\section{Materials and Methods}

\section{Preparation of aqueous extract of Rose hip fruit (Rosa canina)}

The dried fruit of Rosehip was finely powdered. For preparation of extract, $20 \mathrm{~g}$ of rosehip was boiled in $50 \mathrm{~mL}$ deionized water for $2 \mathrm{~min}$. The aqueous extract was subsequently filtered through whatman no. 1 filter paper and then was stored at $4^{\circ} \mathrm{C}$ until further use.

\section{Biosynthesis of silver nanoparticles}

For the synthesis of silver nanoparticles (RAgNPs), $5 \mathrm{~mL}$ of rosehip extract was mixed with $95 \mathrm{~mL}$ of $\mathrm{AgNO}_{3}(5 \mathrm{mM})$. The reaction mixture was incubated at microwave oven $(1200 \mathrm{~W}, 50 \mathrm{~Hz})$ for $1 \mathrm{~min}$. The progress of the reaction was routinely monitored by observing colour change from yellow to brown, which indicated the formation of R-AgNPs. 


\section{Characterization of silver nanoparticles}

A combination of analytical techniques was utilized to characterize the synthesized R-AgNPs including UV-vis Spectroscopy, Scanning Electron Microscopy (SEM) and Energy Dispersive X-ray Spectroscopy (EDX). UV-Vis spectrophotometer (T60, PG Instruments) was used to confirm the reduction of metal ions and was scanned in the range of $300-700 \mathrm{~nm}$.

\section{Cell culture}

The human colon adenocarcinoma cell Line HT29 obtained from Animal Cell Culture Collection (HUKUK, Sap Institute, Ankara, Turkey) were cultured DMEM (Dulbecco's Modified Eagles Medium), supplemented with $10 \%$ heat inactivated Fetal Bovine serum (FBS), Lglutamine, $100 \mu \mathrm{g} / \mathrm{mL}$ Penicillin and $100 \mu \mathrm{g} / \mathrm{mL}$ Streptomycin and were incubated at $37^{\circ} \mathrm{C}$ with $5 \%$ $\mathrm{CO} 2$ in humidified atmosphere.

\section{Cell viability assay}

The cytotoxicity effect of the synthesized RAgNPs on HT29 cancer cells was evaluated by MTT assay. The cells were grown in DMEM medium containing 10\% FBS. For experiments, the cells $\left(1 \times 10^{5}\right.$ cells/well $)$ were plated in 96-well plates with the medium containing 10\% FBS and incubated for $24 \mathrm{~h}$ with $5 \% \mathrm{CO}_{2}$ at $37{ }^{\circ} \mathrm{C}$ in humidified atmosphere. Later, the medium was replaced with DMEM containing $1 \%$ FBS and the R-AgNPs $(20,10,5,2.5,1.25,0.625,0.312,0.156$ and $0.075 \mu \mathrm{g} / \mathrm{mL}$ ). Cells without nanoparticles were used as a control. After treatment, the plates were incubated for $48 \mathrm{~h}$ and $10 \mu \mathrm{L}$ of MTT prepared at a concentration of $5 \mathrm{mg} / \mathrm{mL}$ was added to each well and incubated for $4 \mathrm{~h}$. Purple colour formazan crystals formed were then dissolved in $100 \mu \mathrm{L}$ of dimethylsulphoxide (DMSO). Viability of the cells was evaluated by measuring the absorbance at $570 \mathrm{~nm}$ in a multiwell ELISA plate reader (Multiscan GO, Thermo Fisher Sci.). The absorbance at $570 \mathrm{~nm}$ was also measured for wells without any sample as blank. The $\%$ cell viability was evaluated using the following equation:

Cell viability (\%): (the OD of treated well/the OD of control well) X100

IC50 value was calculated from the dose-response curve obtained with this assay.

\section{Scratch Assay}

Cell migration was determined by using an in vitro scratch assay. HT29 cells were seeded in 24 well culture plates and grown to $100 \%$ confluence. A scratch was made in the monolayer of cells with a sterile pipette tip. Measures were taken to maintain the same scratch angle in the test and control wells. After a scratch was made, the cells were washed with PBS to remove unattached cells. At 10X magnification of an inverted microscope equipped with a camera, images of control and test wells $(0,1 \mu \mathrm{g} / \mathrm{mL}$ and $1 \mu \mathrm{g} / \mathrm{mL}$ R-AgNPs $)$ were captured at $0 \mathrm{~h}, 12 \mathrm{~h}$ and $24 \mathrm{~h}$. Further the captured images were analyzed by Image J software.

\section{Colony formation assay}

The colony formation assay is capable of evaluating in vitro cell death based on the ability of a single cell to transform into a colony. Briefly, cells were seeded as single cells (1000 cells/well) in 6-well plates and allowed to adhere for $24 \mathrm{~h}$. Cells were treated with two different concentrations $(0.1$ and $1 \mu \mathrm{g} / \mathrm{mL}$ ) of AgNPs at $37^{\circ} \mathrm{C}$ for 14 days. At the end of the incubation period, the cells were washed and fixed with methanol for $5 \mathrm{~min}$, and then stained with $0.1 \%$ crystal violet for $15 \mathrm{~min}$ and colony formation in each dish was photographed. The clonogenic index was then determined by counting the cell colonies in each well.

\section{Results}

\section{Biosynthesis of R-AgNPs and Characterization}

In this study, rose hip extract was used to synthesis of R-AgNPs. Figure 1A shows silver nitrate, rosehip extract and R-AgNPs. It was observed that 
the extract had a yellowish-red color before reaction with the silver ions. After a few minutes of mixing the rosehip extract and the AgNO3 solution, a brown color change was observed indicating the formation of AgNPs. Further, the R-AgNPs were characterized using UV-vis spectroscopy. The UV-visible absorption spectra of R-AgNPs were measured in the range of the wavelength range $300-750 \mathrm{~nm}$. A surface plasmon peak was observed at $430 \mathrm{~nm}$ for the R-AgNPs (Figure 1B). The surface nature of the R-AgNPs were determined by SEM. (Figure 1C). It was seen that according to EDX, there were peaks of $\mathrm{Ag}$ metal in the elemental composition of R-AgNPs (Figure 1D).
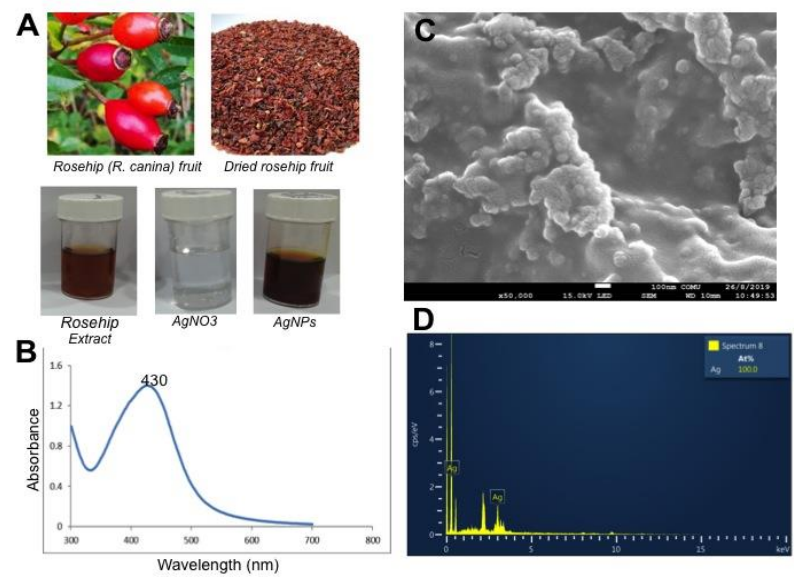

Figure 1. Biosynthesis of R-AgNPs (A), UV-vis spectrum of synthesized R-AgNPs (B), SEM image of synthesized R-AgNPs (C), EDX spectrum of R-AgNPs (D).

\section{AgNPs-induced cytotoxicity in HT29 human colon adenocarcinoma cells}

The cytotoxicity potential of the biosynthesized RAgNPs on human colon cancer cells has been examined using the HT29 cell line. The cells were exposed to various concentrations of AgNPs for $48 \mathrm{~h}$, then the cytotoxicity effects of R-AgNPs assessed using the MT'T [3-(4,5-dimethylthiazol-2yl)-2,5-diphenyl tetrazolium bromide] assay. The MTT results showed that the AgNPs decreased cell viability in terms of dose and time compared to control group (Figure 2). The inhibitory concentration (IC50 value) was calculated to be
$7,98 \mu \mathrm{g} / \mathrm{mL}$ after $48 \mathrm{~h}$ of cell treatment.

In cytotoxicity studies, colony forming assay is one of the standard method for verifying clonogenic survival ability of cells exposed to potential therapeutic agent. After treatment with R-AgNPs, a colony formation assay was performed to measure the proliferation of HT29 cancer cells. HT29 cancer cells were seeded at appropriate dilutions and treated with two different concentrations of R-AgNPs $(0.1$ and $1 \mu \mathrm{g} / \mathrm{mL})$. Cultures were kept under normal culture conditions for 14 days and the colony formations were analyzed. The results showed that R-AgNPs treatment inhibited significantly the colony forming ability of HT29 cells in a dose dependent manner (Figure 3).

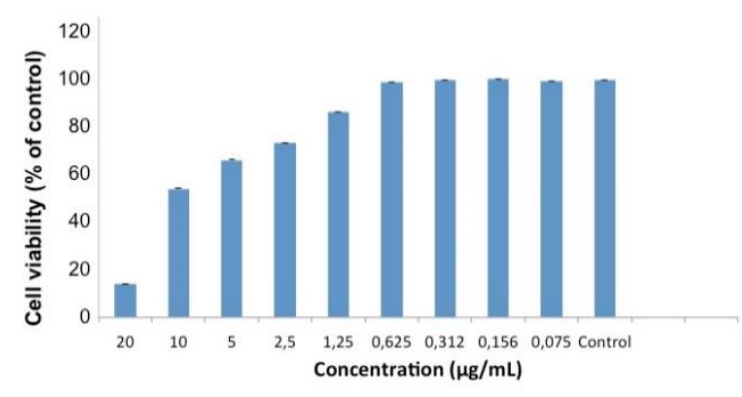

Figure 2. The results of the MTT assay in HT29 colon cancer cells treated with R-AgNPs for 48 h.

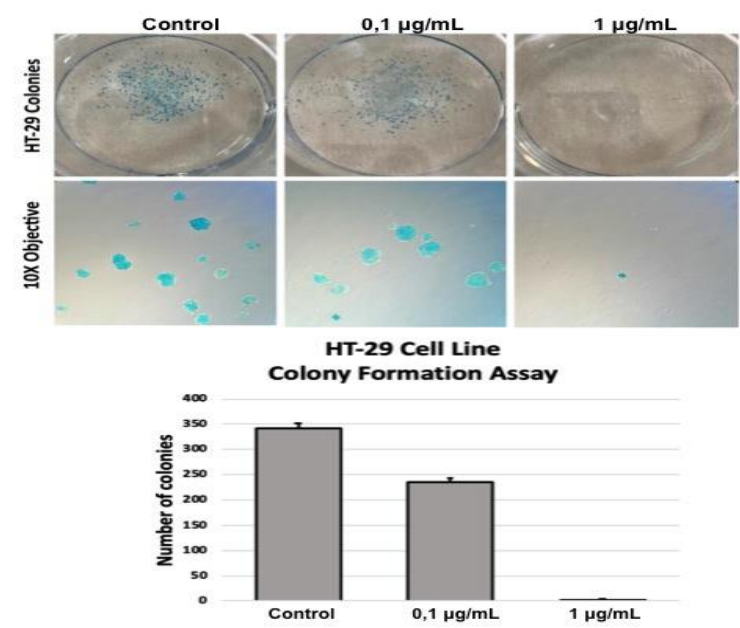

Figure 3. Effect of R-AgNPs on clonogenicity of HT29 colon cancer cells. Colony formation was analyzed by crystal violet staining (A) The clonogenic index was determined by counting the cell colonies in each well (B). 
Metastasis is a hallmark of cancer progression and the leading cause of mortality among cancer patients (Hanahan and Weinberg, 2011). The migration of cancer cells is the first step in metastasis, and these process called as tumor invasion (Clark and Vignjevic, 2015). The in vitro scratch assay is a simple and commonly used method to measure cell migration (Liang et al., 2007). Thus, we have used in vitro scratch assay to evaluate the effect of R-AgNPs on cell migration. Our results showed that the R-AgNPs treatment reduced migration ability of colon cancer cells HT29 at period of $12 \mathrm{~h}$ and $24 \mathrm{~h}$. R-AgNPs at 1 $\mu \mathrm{g} / \mathrm{mL}$ concentration showed more effective inhibitory cell migration determined through scratch assay (Figure 4).

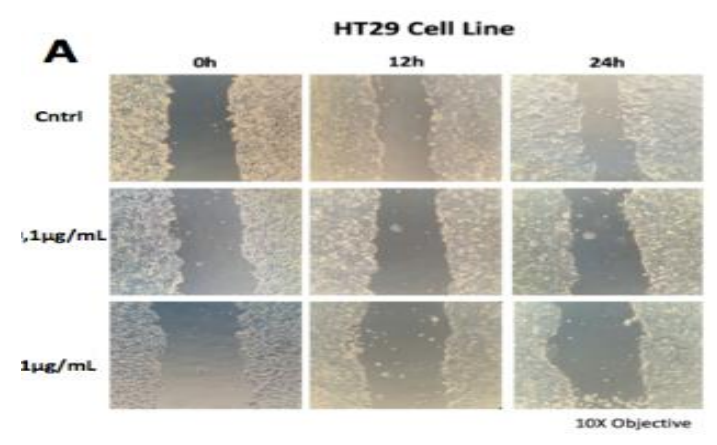

B

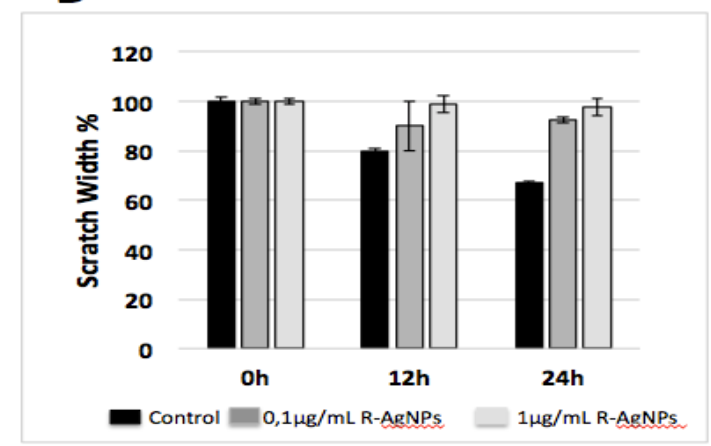

Figure 4. Effects of R-AgNPs on HT29 colon cancer cell migration, assessed by scratch assay. HT29 cells were imaged with a inverted microscope (original magnification, $\times 10$ ) at 0,12 and $24 \mathrm{~h}$ post-scratching. The images were analyzed by Image J software.

\section{Discussion}

Metal nanoparticles are sophisticated agents with a broad range of applications in various field. In particular, silver nanoparticles have great potential as antimicrobial agents, diagnostic tools, imaging, biomedical device coating tools, drug and gene delivery carriers in nanomedicine (Panacek., 2006). Different methods are available for the synthesis of silver nanoparticles. However, the use of highly toxic and harmful to the environment materials is a necessity in many methods used in the production of silver nanoparticles. Furthermore, nanoparticle production with these methods is limited, expensive and harmful to the environment due to high-energy dissipation (Mathur., 2017). The biological method used in the production of nanoparticles uses biological resources such as plants, algae, fungi, yeasts and bacteria.

In this study, we tried to define the synthesis of RAgNPs with rosehip extract and then further use of synthesized nanoparticles for clinical purposes. The synthesized R-AgNPs were characterized via UV-vis spectrophotometry and SEM. It is known that the characteristic absorption peak of AgNPs is centered at 400-450 $\mathrm{nm}$ depending on the size and distribution of the nanoparticles (Anandalakshmi et al., 2016). In our study, an absorption peak at $430 \mathrm{~nm}$ was observed, suggesting that the synthesized R-AgNPs were pure. It is well known that a strong surface plasmon peak is observed in the presence of various metal nanoparticles with a width of 2-100 nm (Sastry et al., 1997; Sastry et al., 1998).

Recently, many studies have suggested that the biosynthesized silver nanoparticles from plant extracts have a encouaring cytotoxicity effect against tumor cells (Venugopal et al., 2016; Das et al., 2013; Behboodi et al., 2018; Alavi and Karimi, 2017). In the literature, the cytotoxic and anticancer effects of the extracts obtained from Rosa canina have been reported against several cancer cells (Kilinc et al., 2019; Turan et al., 2018; Jiménez et al., 2016). The plant extracts used in these studies were able to inhibit the growth of cancer cells at much higher concentrations than nanoparticles. There is only one study showing the use of Rosa canina in silver nanoparticle synthesis and a different method has been used. However, 
the effects of nanoparticles on cancer cells were not evaluated in this study (Pulit et al., 2014).

In our study, silver nanoparticle synthesis was performed for the first time by using Rosa canina extract and its anti-cancer and anti-metastatic effects were evaluated on HT29 colon cancer cells. The in vitro cytotoxic effect of R-AgNPs and cell inhibition (\%) was evaluated by MTT assay compare to the control group. Untreated cells constituted the control group. The results of MTT assay showed that the increasing concentrations of biosynthesized R-AgNPs enhanced the inhibitory effect on the cell proliferation of HT29 cells after $48 \mathrm{~h}$ exposure. The $\mathrm{IC}_{50}$ value of biosynthesized R-AgNPs was determined to be $7,98 \mu \mathrm{g} / \mathrm{mL}$. The approximately $90 \%$ cell inhibition of colon cancer cells was observed at a maximum concentration of $20 \mu \mathrm{g} / \mathrm{mL}$.

Grunathan et al. (2018) reported that the narigenin-mediated synthesis of AgNPs were very effective at low concentrations against HCT116 colorectal cancer cells (IC 50:5 $\mathrm{\mu g} / \mathrm{mL}$ ) Anthemis atropatana extract-mediated synthesis of AgNPs showed dose dependent cytotoxic effects against colon cancer cell lines (HT29) (Dehghanizade et al., 2018). Similarly, Abutilon indicum-mediated AgNPs exhibited dose-dependent antiproliferative effects on COLO 205 (human colon cancer) (IC 50 : $3 \mu \mathrm{g} / \mathrm{mL}$ ) and MDCK (normal) cells (IC $50: 75$ $\mu \mathrm{g} / \mathrm{mL}$ ) (Mata et al., 2015). Likewise, Durai et al. (2014) reported that the para-hydroxybenzoate tetrahydrate (SPHT)-mediated synthesis of AgNPs showed dose- and time-dependent inhibition of cell viability on HCT15 and HT-29 colon cancer cell lines ( $\mathrm{IC}_{50}: \quad 8 \mu \mathrm{g} / \mathrm{mL}$ ). In this study, the potential cytotoxic effect of RAgNPs on HT29 cells after short (48 hours) and long term (two weeks) exposure were demonstrated. In addition to MTT assay (48 hours), colony formation assay was performed to evaluate cell proliferation. Colony formation assay, used to evaluate the cytotoxic effects induced after long term exposure (two weeks). R-AgNPs was added at different concentrations $(0,1$ and $1 \mu \mathrm{g} / \mathrm{mL}$ ) and colonies were counted and analyzed after two weeks. The results showed that RAgNPs inhibited HT29 colony formation as compared to the control cells (Figure 3). This result shows that R-AgNPs reduce the colonyforming potential of cancer cells and therefore can be used as an anti-cancer drug. The small number of colonies formed by cells exposed to R-AgNPs $(1 \mu \mathrm{g} / \mathrm{mL})$ confirmed the MTT assay cytotoxicity. In the literature, clonogenic assay data were not found in any study that tested plant-mediated AgNPs in colon cancer cells.

In this study, the R-AgNPs inhibited lateral motility of HT29 cells in dose dependent manner. According to our results, the dose of $1 \mu \mathrm{g} / \mathrm{mL}$ inhibited lateral motility by $97.4 \%$ for $24 \mathrm{~h}$ (Figure 4). The R-AgNPs showed the remarkable effect on cancer cell proliferation and migration. Also, the ability of R-AgNPs to show activity even at low concentrations may make them useful for in vivo experiments. There are few studies investigating the anti-metastatic effects of silver nanoparticles. The results of our study are consistent with previous studies reporting that silver nanoparticles inhibit the migration of cancer cells (Hussain et al., 2019; Shruti et al., 2015; Kavaz et al., 2018; Buranasukhon et al., 2017).

In conclusion, the silver nanoparticles were successfully synthesized from Rosa canina extract. The biosynthesized R-AgNPs exhibited anticancer and anti-metastatic effects against HT29 human colon cancer cells. Based on our findings, we suggest that biosynthesized AgNPs may be promising new therapeutic agents for the treatment of human colon cancer. Further studies are required to support our findings of the anticancer and anti-metastatic potential of biosynthesized AgNPs in vivo.

\section{Conflicts of Interest}

The authors declare no conflict of interest.

* This study was presented as an oral presentation at the $2^{\text {nd }}$ International Conference on Technology and Science, 2019 on November 14- 16, 2019, Burdur-Turkey. 


\section{References}

Ahmed, S., Ahmad, M., Swami, B.L., Ikram, S.A., 2016. Review on plants extract mediated synthesis of silver nanoparticles for antimicrobial applications: a green expertise. Journal of Advanced Research 7(1), $17-28$.

Alavi, M., Karimi, N., 2017. Characterization, antibacterial, total antioxidant, scavenging, reducing power and ion chelating activities of green synthesized silver, copper and titanium dioxide nanoparticles using Artemisia haussknechtii leaf extract. Artificial Cells, Nanomedicine, and Biotechnology 12, 1-16.

Albrecht, M.A., Evan, C.W., Raston, C.R., 2006. Green chemistry and the health implications of nanoparticles. Green Chemistry 8, 417-32.

Anandalakshmi, K., Venugobal, J., Ramasamy, V., 2016. Characterization of silver nanoparticles by green synthesis method using Pedalium murex leaf extract and their antibacterial activity. Applied Nanoscience 6, 399408.

Behboodi, S.,_Baghbani-Arani, F.,_Abdalan, S.,_Sadat Shandiz, S.A., 2018._Green Engineered Biomolecule-Capped Silver Nanoparticles Fabricated from Cichorium intybus Extract: In Vitro Assessment on Apoptosis Properties Toward Human Breast Cancer (MCF-7). Cells. Biological Trace Element Research 187(2), 392-402.

Bray, F., Ferlay, J., Soerjomataram, I., Siegel, R.L., Torre, L.A., Jemal, A., 2018. Global cancer statistics 2018: GLOBOCAN estimates of incidence and mortality worldwide for 36 cancers in 185 countries. CA Cancer Journal for Clinicians 68(6), 394-424.

Buranasukhon, W., Athikomkulchai, S., Tadtong, S., and Chittasupho, C., 2017. Wound healing activity of Pluchea indica leaf extract in oral mucosal cell line and oral spray formulation containing nanoparticles of the extract. Pharmaceutical Biology 55, 1767-1774.

Cheng, B.C., Fua, X.Q., Guo, H., 2016. The genus Rosa and arthritis: overview on pharmacological perspectives. Pharmacological Research 114, 219-234.

Chrubasik, J.E., Roufogalis, B.D., Chrubasik, S., 2007. Evidence of effectiveness of herbal antiinflammatory drugs in the treatment of painful osteoarthritis and chronic low back pain. Phytotherapy Research 21(7), 675-83.

Clark, A.G., Vignjevic, D.M., 2015. Modes of cancer cell invasion and the role of the microenvironment. Current Opinion in Cell Biology 36, 13-22.

Daphne, J., Francis, A., Mohanty, R., Ojha, N.,
Das, N., 2018. Green Synthesis of Antibacterial Silver Nanoparticles using Yeast Isolates and its Characterization. Research Journal of Pharmacy and Technology 11(1), 83-92.

Das, S., Das, J., Samadder, A., Bhattacharyya, S.S., Das, D., Khuda- Bukhsh, A.R., 2013. Biosynthesized silver nanoparticles byethanolic extracts of Phytolacca decandra, Gelsemium sempervirens, Hydrastis canadensis and Thuja occidentalis induce differential cytotoxicity through G2/M arrest in A375 cells. Colloids and Surfaces B: Biointerfaces 101, 325-336

Dehghanizade, S., Arasteh, J., Mirzaie, A., 2018. Green synthesis of silver nanoparticles using Anthemis atropatana extract: characterization and in vitro biological activities. Artificial Cells, Nanomedicine, and Biotechnology 46(1), 160-168.

Durai, P., Chinnasamy, A., Gajendran, B., Ramar, M., Pappu, S., Kasivelu, G., Thirunavukkarasu, A., 2014. Synthesis and characterization of silver nanoparticles using crystal compound of sodium parahydroxybenzoate tetrahydrate isolated from Vitex negundo. $L$ leaves and its apoptotic effect on human colon cancer cell lines. Europen Journal of Medicinal Chemistry 84, 90-9.

Gurunathan, S., Qasim, M., Park, C., Yoo, H., Kim, J.H., Hong, K., 2018. Cytotoxic Potential and Molecular Pathway Analysis of Silver Nanoparticles in Human Colon Cancer Cells HCT116. International Journal of Molecular Sciences 19(8). pii: E2269.

Hanahan, D., Weinberg, R.A., 2011. Hallmarks of cancer: the next generation. Cell 144, 646-674.

Hussain, A., Alajmi, M.F., Khan, M.A., Pervez, S.A., Ahmed, F., Amir, S., Husain, F.M., Khan, M.S., Shaik, G.M., Hassan, I., Khan, R.A., Rehman, M.T., 2019. Biosynthesized Silver Nanoparticle (AgNP) From Pandanus odorifer Leaf Extract Exhibits Anti-metastasis and Anti-biofilm Potentials. Frontiers in Microbiolgy 10, 8.

Iravani, S., 2011. Green synthesis of metal nanoparticles using plants. Green Chemistry 13, 2638.

Jiménez, S., Gascón, S., Luquin, A., Laguna, M., Ancin-Azpilicueta, C., Rodríguez-Yoldi, M.J., 2016. Rosa canina Extracts Have Antiproliferative and Antioxidant Effects on Caco-2 Human Colon Cancer. PLoS One 11(7), e0159136.

Kavaz, D., Umar, H., Shehu, S., 2018. Synthesis, characterization, antimicrobial and antimetastatic activity of silver nanoparticles synthesized from Ficus ingens leaf. Artificial Cells, Nanomedicine, and Biotechnology 46(sup3), 1193-1203. 
Kilinc, K., Demir, S., Turan, I., Mentese, A., Orem, A., Sonmez, M., Aliyazicioglu, Y., 2019. Rosa canina Extract has Antiproliferative and Proapoptotic Effects on Human Lung and Prostate Cancer Cells. Nutrition and Cancer 11, 1-10.

Larsen, E., Kharazmi, A., Christensen, L.P., Christensen, S.B., 2003. An antiinflammatory galactolipid from rose hip (Rosa canina) that inhibits chemotaxis of human peripheral blood neutrophils in vitro. Journal of Natural Products 66(7), 994-5.

Liang, C.C., Park, A.Y., Guan, J.L., 2007. In vitro scratch assay: a convenient and inexpensive method for analysis of cell migration in vitro. Nature Protocols 2(2), 329.

Mármol, I., Sánchez-de-Diego, C., JiménezMoreno, N., Ancín-Azpilicueta, C., RodríguezYoldi, M.J., 2017. Therapeutic Applications of Rose Hips from Different Rosa Species. International Journal of Molecular Science 18(6), pii: E1137.

Mata, R., Nakkala, J.R., Sadras, S.R., 2015. Biogenic silver nanoparticles from Abutilon indicum: Their antioxidant, antibacterial and cytotoxic effects in vitro. Colloids and Surfaces B: Biointerfaces 128, 276-286.

Mathur, P., Jha, S., Ramteke. S., Jain, N.K., 2017. Pharmaceutical aspects of silver nanoparticles. Artificial Cells, Nanomedicine, and Biotechnology 12, 1-12.

Panacek, A., Kvítek, L., Prucek, R., Kolar, M., Vecerova, R., Pizúrova, N., Sharma, V.K., Nevecna, T., Zboril, R., 2006. Silver colloid nanoparticles: synthesis, characterization, and their antibacterial activity. Journal of Physical Chemistry B 110, 16248-53.

Pulit, J., Banach, M., 2014. Preparation of nanosilver and nanogold based on $\operatorname{dog}$ rose aqueous extract. Bioinorganic Chemistry and Applications 2014:658935

Raveendran, P., Fu, J., Wallen, S.L., 2003. Completely "green" synthesis and stabilization of metal nanoparticles. Journal of the American Chemical
Society 125(46), 13940-13941.

Sastry, M., Mayya, K.S. Bandyopadhyay, K., 1997. $\mathrm{pH}$ Dependent changes in the optical properties of carboxylic acid derivatized silver colloidal particles. Colloids and Surfaces A 127, 221. 27.

Sastry, M., Patil, V., Sainkar, S.R., 1998. Electrostatically controlled diffusion of carboxylic acid derivatized silver colloidal particles in thermally evaporated fatty amine films. Journal of Physical Chemistry B 102(8), 1404-1410.

Shruti, S., Jain, D. S., Athawale, R. B., Bajaj, A. N., Goel, P., Kamran, Z., et al. 2015. Evaluation of antimetastatic potential of Cisplatin polymeric nanocarriers on B16F10 melanoma cells. Saudi Pharmaceutical Journal 23, 341-351.

Slattery, M.L., 2000. Diet, lifestyle, and colon cancer. Seminars in gastrointestinal disease 11, 142-6.

Thakkar, K.N., Mhatre, S.S., Parikh, R.Y., 2010. Biological synthesis of metallic nanoparticles. Nanomedicinee 6, 257-262.

Turan, I., Demir. S., Kilinc, K., Yaman, S.O., Misir, S., Kara, H., Genc, B., Mentese. A., Aliyazicioglu, Y., Deger, O., 2018. Cytotoxic effect of Rosa canina extract on human colon cancer cells through repression of telomerase expression. Journal of Pharmaceutical Analysis 8(6), 394-399.

Venugopal, K., Rather, H. A , Rajagopal, K., Shanthi, M.P., Sheriff. K., Illiyas, M., Rather, R.A., Manikandan, E., Uvarajan, S., Bhaskar, M., Maaza, M., 2017. The impact of anticancer activity upon Beta vulgaris extract mediated biosynthesized silver nanoparticles (Ag-NPs) against human breast (MCF-7), lung (A549) and pharynx (Hep-2) cancer cell lines. Journal of Photochemistry and Photobiology B 167, 282-289.

Yesilot, S., Aydin, C.A., 2019. Silver nanoparticles; a new hope in cancer therapy?. Eastern Journal of Medicine 24(1), 111-116. 